\title{
PENGARUH KUALITAS PELAYANAN TERHADAP KEPUASAN KONSUMEN PADA TOKO RITEL DH MART TULUNGAGUNG
}

\author{
Muhammad Anasrulloh \\ STKIP PGRI Tulungagung \\ anasrulloh_m@stkippgritulungagung.ac.id
}

\begin{abstract}
Kepuasan konsumen atau pelanggan merupakan kunci dalam menciptakan loyalitas pelanggan yaitu dengan memberinkan kualitas pelayan yang baik. Banyak manfaat yang diterima oleh perusahaan dengan tercapainya tingkat kepuasan pelanggan yang tinggi, yakni selain dapat meningkatkan loyalitas pelanggan tapi juga dapat mencegah terjadinya perputaran pelanggan, mengurangi sensitivitas pelanggan terhadap harga, mengurangi biaya kegagalan pemasaran, mengurangi biaya operasi yang diakibatkan oleh meningkatnya jumlah pelanggan, meningkatkan efektivitas iklan, dan meningkatkan reputasi bisnis

Penelitian ini bertujuan untuk mengetahui apakah kualitas pelayanan berpengaruh terhadap kepuasan konsumen Toko Retail DH Mart Tulungagung. Populasi dalam penelitian ini adalah konsumen Toko Retail DH Mart Tulungagung. Dalam penelitian ini data dikumpulkan dengan metode kuesioner terhadap 80 orang responden, yang bertujuan untuk mengetahui tanggapan responden terhadap masing - masing variabel. Analisis yang digunakan meliputi uji validitas, uji reliabilitas, uji normalitas, analisis regresi linear sederhana, uji hipotesis dengan uji t.

Hasil penelitian menunjukkan bahwa kualitas pelayanan berpengaruh terhadap kepuasan konsumen Toko Retail DH Mart Tulungagung.
\end{abstract}

Keywords : Kualitas Pelayanan, Kepuasan konsumen

\section{PENDAHULUAN}

Saat ini, iklim kompetisi dalam dunia perdagangan semakin terasa. Di sisi lain perubahan lingkungan yang demikian pesat semakin mendukung kompetisi yang sedang terjadi saat ini. Menurut Dick dan Basu (1994), salah satu tujuan utama aktivitas pemasaran seringkali dilihat dari pencapaian loyalitas pelanggan melalui strategi pemasaran (Siregar, 2004). Loyalitas pelanggan merupakan bagian terpenting pada pengulangan pembelian pada pelanggan (Caruana, 2002).

Menurut Reichheld dan Sasser (1990), loyalitas pelanggan memiliki korelasi yang positif dengan performa bisnis (Beerli dkk., 2004). Menurut Castro dan Armario (1999), loyalitas pelang-gan tidak hanya meningkatkan nilai dalam bisnis, tetapi juga dapat menarik pelanggan baru (Beerli dkk., 2004). Pada jangka pendek, memperbaiki loyalitas pelanggan akan membawa profit pada penjualan. Profit merupakan motif utama konsistensi bisnis, karena dengan keuntungan maka roda perputaran bisnis dari variasi produk dan jasa yang ditawarkan maupun perluasan pasar yang dilayani (Soeling, 2007). Dalam jangka panjang, memperbaiki loyalitas umumnya akan lebih profitabel, yakni pelanggan bersedia membayar harga lebih tinggi, penyediaan layanan yang lebih murah dan bersedia merekomendasikan ke pelanggan yang baru ("Managing Customer", 1995).

Kepuasan pelanggan merupakan kunci dalam menciptakan loyalitas pelanggan. Banyak manfaat yang diterima oleh perusahaan dengan tercapainya tingkat kepuasan pelanggan yang 
tinggi, yakni selain dapat meningkatkan loyalitas pelanggan tapi juga dapat mencegah terjadinya perputaran pelanggan, mengurangi sensitivitas pelanggan terhadap harga, mengurangi biaya kegagalan pemasaran, mengurangi biaya operasi yang diakibatkan oleh meningkatnya jumlah pelanggan, meningkatkan efektivitas iklan, dan meningkatkan reputasi bisnis (Fornell, 1992).

Keputusan perusahaan melakukan tindakan perbaikan pelayanan yang sistematis merupakan payung yang menentukan dalam menindaklanjuti komplain konsumen dari suatu kegagalan sehingga pada akhirnya mampu mengikat loyalitasi konsumen (Elu, 2005). Kepuasan pelanggan menjadi parameter penting sehingga bisnis dapat terus berkelanjutan. Sebuah riset tahun 2004 yang dilakukan oleh J.D. Power, perusahaan spesialis pengukur kepuasan pelanggan dalam industri otomotif, membuktikan bahwa perusahaan yang berhasil meningkatkan kepuasan pelanggan dalam jangka waktu lima tahun (1999-2004) mengalami kenaikan nilai bagi pemegang sahamnya sebesar $+52 \%$. Sebaliknya, perusahaan yang mengalami penurunan nilai kepuasan pelanggan, pemegang sahamnya juga mengalami penurunan nilai sebesar $-28 \%$. Riset Claes Fornell juga membuktikan, di masa krisis 2008, saham perusahaan dengan Indeks Kepuasan Pelanggan Amerika (American Customer Satisfaction Index/ACSI) yang baik, hanya menurun $-33 \%$, sedangkan perusahaan dengan indeks yang buruk menurun $-55 \%$. Jadi, kepuasan konsumen bukan saja berharga di masa ekonomi baik, tetapi juga di saat ekonomi buruk (Lestari, 2009).

Menurut para akademisi, kepuasan pelanggan merupakan konstruk yang berdiri sendiri dan dipengaruhi oleh kualitas layanan (Oliver, 1980). Kualitas layanan juga dapat mempengaruhi loyalitas pelanggan secara langsung (Zeithaml dkk., 1996) dan mempengaruhi loyalitas pelanggan secara tidak langsung melalui kepuasan (Caruana, 2002). Kualitas layanan mendorong pelanggan untuk komitmen kepada produk dan layanan suatu perusahaan sehingga berdampak kepada peningkatan market share suatu produk. Kualitas layanan sangat krusial dalam mempertahankan pelanggan dalam waktu yang lama. Perusahaan yang memiliki layanan yang superior akan dapat memaksimalkan performa keuangan perusahaan (Gilbert dkk., 2004).

Semakin tingginya tingkat persaingan, akan menyebabkan pelanggan menghadapi lebih banyak alternative produk, harga dan kualitas yang bervariasi, sehingga pelanggan akan selalu mencari nilai yang dianggap paling tinggi dari beberapa produk (Kotler, 2005). Kualitas yang rendah akan menimbulkan ketidakpuasan pada pelanggan, tidak hanya pelanggan yang makan di restoran tersebut tapi juga berdampak pada orang lain. Karena pelanggan yang kecewa akan bercerita paling sedikit kepada 15 orang lainnya. Dampaknya, calon pelanggan akan menjatuhkan pilihannya kepada pesaing (Lupiyoadi dan Hamdani,

2006).

Upaya perbaikan sistem kualitas pelayanan, akan jauh lebih efektif bagi keberlangsungan bisnis. Menurut hasil riset Wharton Business School, upaya perbaikan ini akan menjadikan konsumen makin loyal kepada perusahaan (Lupiyoadi dan Hamdani, 2006). Konsep dari kualitas layanan, kepuasan dan loyalitas saling berhubungan satu dengan yang lain. Secara teoritis, dalam prosesnya dapat memberikan acuan pada penelitian ini, dimana kualitas layanan mempengaruhi loyalitas baik secara langsung maupun mempengaruhi loyalitas secara tidak langsung melalui kepuasan pelanggan.

Pertumbuhan Toko Ritel di Indonesia menunjukkan perkembangan yang relative pesat, melihat indikasi ini, menunjukkan adanya peluang besar bagi pertumbuhan toko ritel. Iklim kompetisi dalam toko ritel pun semakin terasa dengan bermunculannya berbagai toko ritel. Meningkatnya persaingan telah mengarahkan bisnis toko ritel mendiferensiasikan diri mereka terhadap pesaing..

Berdasarkan latar belakang yang telah diuraikan, yang menjadi rumusan masalah pada penelitian ini adalah : Apakah Kualitas Pelayanan berpengaruh terhadap Kepuasan Konsumen pada Toko Ritel DH Mart Tulungagung.

Secara Umum tujuan penelitian ini yaitu : Untuk menganalisis pengaruh Kualitas Pelayanan terhadap Kepuasan Konsumen pada Toko Ritel DH Mart Tulungagung.

Adapun manfaat dari penelitian ini adalah sebagai berikut : 
1. Bagi Perusahaan

Dapat memberikan gambaran dan informasi yang berguna bagi perusahaan dalam melakukan kebijakan dan strategi pemasaran yang berkaitan dengan kualitas pelayanan dan kepuasan konsumen.

\section{Bagi Peneliti Lain}

Sebagai bahan referensi dan informasi bagi peneliti lain yang ingin melakukan penelitian lebih lanjut terutama yang berhubungan dengan kualitas pelayanan dan kepuasan konsumen.

\section{KAJIAN PUSTAKA PENGEMBANGAN HIPOTESIS}

\section{Kualitas Pelayanan}

Modernitas dengan kemajuan teknologi akan mengakibatkan persaingan yang sangat ketat untuk memperoleh dan mempertahankan pelanggan. Kualitas pelayanan menjadi suatu keharusan yang harus dilakukan perusahaan supaya mampu bertahan dan tetap mendapat kepercayaan pelanggan. Pola konsumsi dan gaya hidup pelanggan menuntut perusahaan mampu memberikan pelayanan yang berkualitas. Keberhasilan perusahaan dalam memberikan pelayanan yang berkualitas dapat ditentukan dengan pendekatan service quality yang telah dikembangkan oleh Parasuraman, Berry dan Zenthaml (dalam Lupiyoadi,2006:181). Service Quality adalah seberapa jauh perbedaan antara harapan dan kenyataan para pelanggan atas layanan yang mereka terima. Service Quality dapat diketahui dengan cara membandingkan persepsi pelanggan atas layanan yang benar-benar mereka terima dengan layanan sesungguhnya yang mereka harapkan. Kualitas pelayanan menjadi hal utama yang diperhatikan serius oleh perusahaan, yang melibatkan seluruh sumber daya yang dimiliki perusahaan.

Definisi mutu jasa berpusat pada pemenuhan kebutuhan dan keinginan pelanggan serta ketepatan penyampaian untuk mengimbangi harapan pelanggan. Menurut Wyckof (dalam Wisnalmawati, 2005:155) kualitas jasa adalah tingkat keunggulan yang diharapkan dan pengendalian atas tingkat keunggulan untuk memenuhi keinginan pelanggan. Apabila jasa yang diterima sesuai dengan yang diharapkan, maka kualitas jasa dipersepsikan baik dan memuaskan. Jika jasa yang diterima melampaui harapan pelanggan, maka kualitas jasa dipersepsikan ideal.

Sebaliknya jika jasa yang diterima lebih rendah dari pada yang diharapkan, maka kualitas jasa dianggap buruk (Tjiptono, 2005:121). Mengacu pada pengertian kualitas layanan tersebut maka konsep kualitas layanan adalah suatu daya tanggap dan realitas dari jasa yang diberikan perusahaan. Kualitas pelayanan harus dimulai dari kebutuhan pelanggan dan berakhir pada persepsi pelanggan (Kotler, 1997) dalam Wisnalmawati (2005:156). Hal ini berarti bahwa kualitas yang baik bukanlah berdasarkan persepsi penyediaan jasa, melainkan berdasarkan persepsi pelanggan. Kualitas layanan mengacu pada penilaian-penilaian pelanggan tentang inti pelayanan, yaitu si pemberi pelayanan itu sendiri atau keseluruhan organisasi pelayanan, sebagian besar masyarakat sekarang mulai menampakkan tuntutan terhadap pelayanan prima, mereka bukan lagi sekedar membutuhkan produk yang bermutu tetapi mereka lebih senang menikmati kenyamanan pelayanan (Roesanto, 2000) dalam Tasunar (2006:44). Oleh karena itu dalam merumuskan strategi dan program pelayanan, organisasi harus berorientasi pada kepentingan pelanggan dan sangat memperhatikan dimensi kualitasnya (Suratno dan Purnama, 2004:74).

Adapun dimensi-dimensi tersebut yaitu: Tangibles atau bukti fisik, Reliability atau keandalan Responsiveness atau ketanggapan, Assurance atau jaminan/kepastian, Empathy atau kepedulian.

\section{Kepuasan Pelanggan / Konsumen}

Dewasa ini perhatian terhadap kepuasan maupun ketidakpuasan pelanggan telah semakin besar karena pada dasarnya tujuan dari suatu perusahaan adalah untuk menciptakan rasa puas pada pelanggan. Semakin tinggi tingkat kepuasan pelanggan, maka akan mendatangkan keuntungan yang semakin besar bagi perusahaan, karena pelanggan akan melakukan pembelian ulang terhadap produk perusahaan. Namun, apabila tingkat kepuasan yang dirasakan pelanggan kecil, maka terdapat kemungkinan bahwa pelanggan tersebut akan pindah ke produk pesaing.

Menurut Kotler, kepuasan adalah tingkat perasaan seseorang setelah membandingkan 
kinerja atau hasil yang dia rasakan dibandingkan dengan harapannya (Kotler dkk, 2000 : 52). Sedangkan Tse dan Wilton (1988) dalam Lupiyoado (2004:349) kepuasan atau ketidakpuasan pelanggan adalah respon pelanggan terhadap evaluasi ketidaksesuaian (disconfirmation) yang dirasakan antara harapan sebelumnya dan kinerja aktual produk yang dirasakan setelah pemakaiannya.

Kepuasan pelanggan merupakan respons pelanggan terhadap ketidaksesuaian antara tingkat kepentingan sebelumnya dan kinerja aktual yang dirasakannya setelah pemakaian (Rangkuti, 2002:30). Kepuasan pelanggan dipengaruhi oleh persepsi kualitas jasa, kualitas produk, harga dan faktor-faktor yang bersifat pribadi serta yang bersifat situasi sesaat. Dari berbagai pendapat yang dilontarkan para ahli bisa disimpulkan definisi kepuasan pelanggan adalah respon dari perilaku yang ditunjukkan oleh pelanggan dengan membandingkan antara kinerja atau hasil yang dirasakan dengan harapan. Apabila hasil yang dirasakan dibawah harapan, maka pelanggan akan kecewa, kurang puas bahkan tidak puas, namun sebaliknya bila sesuai dengan harapan, pelanggan akan puas dan bila kinerja melebihi harapan, pelanggan akan sangat puas.

\section{METODE PENELITIAN}

Penelitian ini dilakukan di DH Mart Tulungagung.

Waktu penelitian dimulai pada bulan Pebruari 2018 sampai dengan bulan Juni 2018.

\section{Variabel Penelitian}

1. Variabel Bebas (independent variable) $(X)$

Yang dimaksud dengan varibel bebas menurut Sugiarto, dkk (2003 : 15) adalah "variabel yang menjadi sebab terjadinya (terpengaruhnya) variabel dependen atau variabel tak bebas." Sedangkan menurut Sugiyono (2007 : 4) "Variabel bebas adalah merupakan variabel yang mempengaruhi atau menjadi sebab perubahannya atau timbulnya variabel dependen (terikat)." Berdasarkan pengertian tersebut dapat disimpulkan bahwa variabel bebas adalah variabel yang mempengaruhi variabel terikat. Variabel bebas dalam penelitian ini adalah kualitas pelayanan $(\mathrm{X})$.
2. Varibel Terikat (dependent varible) $(Y)$

Yang dimaksud dengan varibel terikat menurut Sugiarto, dkk (2003 : 15) adalah "variabel yang nilainya dipengaruhi oleh variabel independen." Sedangkan menurut Sugiyono (2007 : 4) "Variabel terikat merupakan variabel yang dipengaruhi atau yang menjadi akibat, karena adanya variabel bebas. Dari pengertian di atas dapat disimpulkan bahwa variabel terikat adalah variabel yang nilainya dipengaruhi atau yang menjadi akibat, karena adanya variabel bebas.

Dalam penelitian ini variabel yang dipengaruhi atau variabel bebas (Y) yaitu kepuasan konsumen DH Mart Tulungagung.

\section{Definisi Operasional Variabel}

Definisi operasional dalam penelitian ini meliputi :

1. Kualitas pelayanan adalah seberapa jauh perbedaan antara harapan dan kenyataan para pelanggan atas layanan yang mereka terima. Adapun indikator-indikator kualitas pelayanan dalam penelitian ini adalah ; 1) Reliability, 2) Responsiveness, 3) Assurance dan 4) Emphaty

2. Kepuasan Konsumen (Y)

Kepuasan konsumen adalah tingkat perasaan senang atau kecewa seseorang setelah membandingkan kinerja atau hasil yang ia rasakan dibanding dengan harapannya. Umumnya harapan pelanggan merupakan perkiraan atau keyakinan pelanggan tentang apa yang akan diterimanya bila ia membeli atau mengkonsumsi suatu produk. Sedangkan kinerja yang dirasakan adalah daya tanggap pelanggan terhadap apa yang diterima setelah mengkonsumsi produk yang dibeli. Adapun indikator-indikator dari kepuasan konsumen dalam penelitian ini adalah :

a. Kenyamanan yang dirasakan pelanggan pada saat pelayanan diberikan

b. Keyakinan pelanggan atas pelayanan yang diberikan

c. Minat untuk selalu membeli produk

d. Perasaan puas atas perhatian dan pelayanan yang diberikan oleh karyawan.

\section{Metode Pengumpulan Data}

Untuk mendapatkan data-data yang sesuai dengan tujuan penelitan maka dibutuhkan suatu 
teknik pengumpulan data. Metode pengumpulan data yang akan digunakan dalam penelitian ini adalah dengan menggunakan angket yang berisi kuesioner. Angket tersebut diberikan kepada para responden dan kemudian responden akan mengisinya sesuai dengan pendapat dan persepsi responden. Dua kuesioner yang akan digunakan yaitu ; kuesioner kualitas pelayanan dan kepuasan konsumen.

Menurut Sugiono (1999:75) angket merupakan suatu metode pengumpulan data dengan menggunakan daftar pertanyaan/pernyataan (kuesioner) yang harus diisi oleh setiap responden penelitian, sehingga peneliti mendapatkan kesimpulan tentang informasi yang ingin diperoleh. Teknik ini memberikan tanggung jawab bagi responden yang dijadikan subjek penelitian untuk memilih dan menjawab pertanyaan/pernyataan.

Variabel dalam penelitian ini diukur dengan menggunakan skala likert yang mempunyai interval 1-5. Untuk Jawaban yang mendukung pernyataan diberi skor tertinggi dan untuk jawaban yang tidak mendukung pernyataan diberi skor terendah, adapun penentuan skor tersebut adalah sebagai berikut.

1. Untuk jawaban Sangat Setuju (SS) diberi skor 5

2. Untuk jawaban Setuju (S) diberi skor 4

3. Untuk jawaban Ragu-ragu (R) diberi skor 3

4. Untuk jawaban Tidak Setuju (TS) diberi skor 2

5. Untuk jawaban Sangat Tidak Setuju (STS) diberi skor 1

\section{Metode Analisis Data}

1. Uji Validitas dan Reliabilitas Instrumen

Suatu instrumen adalah valid apabila rhitung lebih besar dari r-tabel pada taraf kepercayaan tertentu, kemudian juga dengan melihat Correlations dengan membandingkan Sig. (2-tailed) dengan alpha 0,05\%, apabila nilai signifikansi $>\alpha$ maka instrumen adalah Valid atau dapat dipercaya untuk digunakan sebagai alat pengumpul data karena instrumen tersebut sudah baik.

Untuk mengetahui reliabilitas dapat dilakukan dengan analisis program statistic SPSS

\section{a. Pengaruh Varibel}

(Statiscal Product and Service Solutions) dengan melihat nilai Alpha Cronbach's, menurut Suyuti dalam (Sujianto, 2009 : 97) "kuesioner dinyatakan reliabel jika mempunyai nilai koefisien alpha yang lebih besar dari 0,6." Dari pengertian tersebut dapat disimpulkan bahwa suatu instrument dinyatakan reliabel apabila nila Alpha Cronbach's lebih besar dari 0,6.

2. Uji t

Uji koefisien regresi digunakan untuk menguji tingkat signifikansi variabel bebas terhadap variabel terikat.

3. Analisis Regresi Linier sederhana

Analisis Regresi Linier sederhana adalah menganalisis nilai pengaruh variabel bebas terhadap variabel terikat untuk membuktikan ada atau tidaknya hubungan fungsi atau hubungan kausal antara dua variabel bebas atau lebih. Adapun persamaan garis regresi sebagai berikut.

$\mathrm{Y}=\mathrm{a}+\mathrm{b}_{1} \mathrm{X}_{1} \quad$ (Riduwan dan

Sunarto, 2007: 108)

Keterangan :

Y : Variabel terikat

a : Intercept/Konstanta

b1 : Koefisien regresi

X1 : Variabel bebas

\section{HASIL DAN PEMBAHASAN}

\section{Hasil Analisis Data dan Pengujian Hipotesis}

Hipotesis yang diajukan dalam penelitian ini adalah ; Terdapat pengaruh kepuasan konsumen terhadap kepuasan konsumen pada Toko Ritel DH Mart Tulungagung. Hasil pengujian hipotesis dalam penelitian ini disajikan dalam tabel sebagai berikut. 


\section{Pengaruh Kualitas Pelayanan terhadap Kepuasan Konsumen pada Toko Ritel DH Mart Tulungagung}

\begin{tabular}{|c|c|c|c|c|c|c|}
\hline \multicolumn{7}{|c|}{ Coefficients $^{\mathrm{a}}$} \\
\hline \multirow{2}{*}{\multicolumn{2}{|c|}{ Model }} & \multicolumn{2}{|c|}{ Unstandardized Coefficients } & Standardized & \multirow[t]{2}{*}{$\mathrm{t}$} & \multirow[t]{2}{*}{ Sig. } \\
\hline & & B & Std. Error & Beta & & \\
\hline \multirow{2}{*}{1} & (Constant) & 3.391 & 1.378 & & 2.460 & .016 \\
\hline & Kualitas Pelayanan & .311 & .023 & .839 & 13.619 & .000 \\
\hline
\end{tabular}

\section{Sumber : Data Primer yang diolah, 2017}

Berdasarkan Tabel menunjukkan bahwa hasil analisis data dan pengujian hipotesis sebagai berikut.

Hasil analisis data tentang pengaruh kualitas pelayanan terhadap kepuasan konsumen pada Toko Ritel DH Mart Tulungagung, menunjukkan nilai $p$ value sebesar 0.000 lebih kecil dari pada $\alpha=0,05$, sehingga Ho ditolak dan

Ha diterima, atau terdapat pengaruh yang signifikan kualitas pelayanan terhadap kepuasan konsumen pada Toko Ritel DH Mart Tulungagung hasil tersebut menunjukkan bahwa kualitas pelayanan di Toko Ritel DH Mart Tulungagung berpengaruh terhadap kepuasan konsumen.

\section{b. Regresi Linier Sederhana}

Hasil Persamaan Regresi Linier Sederhana

Coefficients $^{\mathrm{a}}$

\begin{tabular}{|c|c|c|c|c|c|c|}
\hline \multirow[t]{2}{*}{ Model } & & \multicolumn{2}{|c|}{ Unstandardized Coefficients } & \multirow{2}{*}{$\begin{array}{c}\begin{array}{c}\text { Standardized } \\
\text { Coefficients }\end{array} \\
\text { Beta }\end{array}$} & \multirow[t]{2}{*}{$\mathrm{t}$} & \multirow[t]{2}{*}{ Sig. } \\
\hline & & B & Std. Error & & & \\
\hline & (Constant) & 3.391 & 1.378 & & 2.460 & .016 \\
\hline & Kualitas Pelayanan & .311 & .023 & .839 & 13.619 & .000 \\
\hline
\end{tabular}

a. Dependent Variable: Kepuasan Konsumen

Sumber : Data Primer yang diolah, 2017

Hasil uji regresi linier sederhana dapat dilihat pada Tabel. Berdasarkan persamaan garis regresi yang dijelaskan oleh Riduwan dan Sunarto (2010: 253) yakni $Y=a+b_{1} X_{1}+b_{2} X_{2}$ dan berdasarkan pengamatan nilai $a, b_{1}, b_{2}, \ldots$,bn secara berturut-turut dari atas bisa dilihat pada baris Unstandarized Coefficients B pada Tabel Coefficients Unstandarized Coefficients B pada Tabel Coefficients dapat diperoleh nilai $\mathrm{a}=3.391$, nilai $b_{1}=0.311$. Selanjutnya, nilai $a$, nilai $b_{1}$ dimasukkan ke dalam persamaan garis regresi sehingga dapat disusun persamaan $\mathrm{Y}=3.391+$ $0.311 \mathrm{X}$ dengan penjelasan sebagai berikut :

\section{c. Koefisien Determinasi}

1) a merupakan konstanta yang besarnya 3.391 menyatakan bahwa jika variabel independen (kualitas pelayanan) sebesar 0 (nol), maka nilai variabel dependen (kepuasan konsumen) sebesar 3.391.

2) $b_{1}$ merupakan koefisien regresi dari $X$ (kualitas pelayanan). Koefisien regresi 0.311 menyatakan bahwa setiap penambahan satu satuan variabel $X$ dengan asumsi variabel lain dianggap konstan maka hal ini akan berpengaruh pada peningkatan besarnya $\mathrm{Y}$ sebesar 0.311 .

\section{Koofisien Determinasi}

\begin{tabular}{|l|r|r|c|c|r|}
\hline Model & $\mathrm{R}$ & R Square & $\begin{array}{c}\text { Adjusted R } \\
\text { Square }\end{array}$ & $\begin{array}{c}\text { Std. Error of the } \\
\text { Estimate }\end{array}$ & Durbin-Watson \\
\hline 1 & $.839^{\mathrm{a}}$ & .704 & .700 & 2.244 & 2.050 \\
\hline
\end{tabular}


Berdasarkan nilai Adjusted $\mathrm{R}$ Squared yakni 0,700. Nilai Adjusted $\mathrm{R}$ Squared dikalikan $100 \%$ menjadi $70 \%$. Jadi, pengaruh kualitas pelayanan terhadap kepuasan konsumen pada Toko Ritel DH Mart Tulungagung sebesar $70 \%$, sedangkan sisanya sebesar $30 \%$ dipengaruhi oleh variabel lain di luar penelitian.

Berdasarkan hasil penelitian, maka dapat dijelaskan sebagai berikut.

1. Terdapat pengaruh yang signifikan kualitas pelayanan terhadap kepuasan konsumen pada Toko Ritel DH Mart Tulungagung hasil tersebut menunjukkan bahwa semakin tinggi kualitas pelayanan di Toko Ritel DH Mart Tulungagung akan berpengaruh terhadap tingginya kepuasan konsumen.

2. Pengaruh kualitas pelayanan terhadap kepuasan konsumen pada Toko Ritel DH Mart Tulungagung sebesar $70 \%$, sedangkan sisanya sebesar 30\% dipengaruhi oleh variabel lain di luar penelitian.

Hasil tersebut menguatkan teori yang dikemukakan menurut Oliver dalam (J.Suprapto,2001:233) kepuasan pelayanan adalah "tingkat perasaan seseorang setelah membandingkan kinerja atau hasil yang dirasakannya dengan harapannya". Kualitas pelayanan dan kepuasan konsumen memiliki hubungan yang sangat erat karena penilaian dari kepuasan nasabah tergantung pada kualitas pelayanan yang diberikan oleh Perusahaan yang pada dasarnya mencakup harapan dan hasil yang dirasakan.

Hasil tersebut mendukung penelitian yang dilakukan oleh Widjoyo dkk, yang berjudul Analisa Pengaruh Kualitas Layanan terhadap Kepuasan Konsumen pada Layanan Drive Thru McDonald's Basuki Rahmat di Surabaya (2013). Dan juga Rosinta (2010) Pengaruh Kualitas Layanan terhadap Kepuasan Pelanggan dalam Membentuk Loyalitas Pelanggan.

Pada bagian ini, penulis menyimpulkan hasil penelitian atau review literature, keterbatasan penelitian atau penulisan serta agenda penelitian berikutnya.

\section{SIMPULAN DAN SARAN}

\section{Simpulan}

1. Terdapat pengaruh yang signifikan Kualitas Layanan terhadap Kepuasan Konsumen pada Toko Ritel DH Mart Tulungagung hasil tersebut menunjukkan bahwa semakin tinggi kualitas layanan di Toko Ritel DH Mart Tulunggung berpengaruh terhadap tingginya kepuasan konsumen.

2. Pengaruh Kualitas Layanan terhadap kepuasan konsumen pada Toko Ritel DH Mart Tulungagung sebesar 70\%, sedangkan sisanya $30 \%$ dipengaruhi variable lain.

\section{Saran}

1. Agar kepuasan konsumen di Toko Ritel DH Mart Tulungagung tinggi manajemen perlu meningkatkan kualitas layanan karyawan terhadap konsumen.

2. Untuk meningkatkan kualitas layanan karyawan kepada konsumen perlu mempertimbangakan situasi lingkungan kerja di tempat usaha mendukung aktivitas karyawan dan sarana mendukung serta peralatan kerja memadai dan mendukung kinerja.

\section{Keterbatasan Penelitian}

1. Penelitian ini hanya menggunakan satu variabel independen dan satu variabel dependen, sehingga tidak diketahui hasilnya apabila variabel independen ditambah.

2. Penelitian ini hanya menggunakan data cross section. Data cross section memiliki keterbatasan dalam menerangkan stabilitas hubungan antar variabel yang dilibatkan dalam suatu penelitian dari waktu ke waktu.

3. Untuk penelitian mendatang perlu menindaklanjuti keterbatasan-keterbatasan yang ada dalam penelitian ini, misalnya dengan menambah variabel independen, sehingga menghasilkan kajian yang lebih sempurna. 
Implementasi, dan Pengendalian. Selemba Empat. Jakarta.

\section{DAFTAR PUSTAKA}

Cahyadi, Eko. 2003. Kualitas Pelayanan, Kepuasan dan Loyalitas Pelanggan Pada Industri perbankan Islam Dengan Menggunakan Metode CARTER (Kasus Bank Mualamat Indonesia Cabang Rawamangun). Skripsi Fakultas Ilmu Sosial dan Ilmu Politik Universitas Indonesia, tidak diterbitkan.

Caruana, A. 2002. Service Loyalty The Effects of Service Quality and The Mediating Role of Customer Satisfaction. European Journal of Marketing, 36.

Caruana, Albert, 2002. Service Loyalty The Effects of service quality and the mediating role of customer satisfaction, Europen Journal of Marketing,. Vol. 36,

Elu, Balthasar. 2005. Manajemen Penanganan Komplain Konsumen di Industri Jasa. Jurnal Ilmu Administrasi dan Organisasi, Bisnis\&Birokrasi, Vol. 13, No. 3 (September).

Fornell, C. 1992. A National Customer Satisfaction Barometer: The Swedish Experience. Journal of Marketing, 56.

Freddy Rangkuti. 2002. Measuring Customer Satisfaction (cetakan ketiga). Jakarta : PT.Gramedia Pustaka Utama.

Journal of the Academy of Marketing Science/ Customer loyalty: Toward an integrated conceptual framework/ Dick, A.S. \& Basu, K. JAMS (1994)

Kotler, Philip. 2000. Manajemen Pemasaran di Indonesia : Analisis, Perencanaan, Implementasi, dan Pengendalian. Selemba Empat. Jakarta.

Kotler, Philip. 2002. Manajemen Pemasaran di Indonesia : Analisis, Perencanaan,
Kotler, Philip. 2005. Manajemen Pemasaran Jilid 1 (11th ed.) (Benyamin Molan, Penerjemah). Jakarta: PT. Indeks.

Lestari, E. 2009. Menyimak Kepuasan Pelanggan di Mancanegara.

Lupiyoadi, R \& Hamdani, A. 2006. Manajemen Pemasaran Jasa. Jakarta: Salemba Empat.

M. Nur Nasution. 2004. Manajemen Jasa Terpadu. Bogor: Ghalia Indonesia.

Manajemen Aset/by Doli D. Siregar/ Published 2004 by PT Gramedia Pustaka Utama

Nanang Tasunar. 2006. "Kualitas Layanan Sebagai Strategi Menciptakan Kepuasan pada Pangkalan Pendaratan Ikan (PPI) Morodemak". Jurnal Sains Pemasaran Indonesia, Vol. V, No. 1 Mei 2006, h. 4162

Oliver, R.L. 1980. A Cognitive Model of The Antecedents and Consequences of Satisfaction Decisions. Journal of Marketing Research, 17.

Parasuraman, A., Zeithaml, V.A., \& Berry, L.L. 1985. A Conceptual Model of Service Quality And Its Implications for Future Research. The Journal of Marketing, 49.

Siregar, S.P. 2004. Analisis Kepuasan Para Anggota Terhadap Program Loyalitas Astraworld. Tesis Fakultas Ekonomi. Universitas Indonesia, tidak diterbitkan.

Soeling, Pantius D. 2007, Pertumbuhan Bisnis dan Tanggung jawab sosial perusahaan. Jurnal Ilmu Administrasi dan Organisasi,

Sri Suratno F.G. dan Nursya' Bani Purnama. 2004. "Analisis Tingkat Kepuasan Wajib Pajak Terhadap Kualitas Layanan Kantor Pelayanan Pajak Yogyakarta Dua". Sinergi Kajian Bisnis dan Manajemen, Vol. 7, No. 1, h. 69-87 
Sunarto. 2003. Manajemen Pemasaran. BPFEUST. Yogyakarta

Sundari, Dina. 2004. Pengaruh Kualitas Pelayanan Jasa Pos Terhadap Kepuasan Konsumen PT. Pos Indonesia Metro. FKIP Unila. Skripsi lampung

Tjiptono, Fandi dan Gregorius Chandra. 2005. Service Quality Satisfaction. Yogyakarta : Penerbit Andi.

Tjiptono, Fandi, 2002, Manajemen Jasa, Yogyakarta : Penerbit Andi

Tjiptono, Fandi 2002, Prinsip-Prinsip Total Quality Service. Yogyakarta : Penerbit Andy

Tjiptono, Fandi, 2004, Strategi Pemasaran, Edisi 2, Penerbit Andi, Yogyakarta.

Tjiptono, Fandi, 2007, Pemasaran Jasa, Bayu Media Publishing, Malang.

Tse, David K. \& Wilton, Peter C., 1988, "Models of Customer Satisfaction Formation: An Extension", Journal of Marketing Research, Vol. 25, May 1988, PG. 204-212.

Wisnalmawati. 2005. Pengaruh Persepsi Dimensi Kualitas Layanan Terhadap Niat pembelian Ulang. Jurnal Ekonomi dan Bisnis, No. 3 Jilid 10 2005, h. 153-

Zeithaml, L. Valerie A., Parasuraman, A., Berry, Leonardo L., 1988, "Servqual; A Multiple Item Scale for Measuring Consumer Perception of Service Quality”, Journal and Retailing, Vol. 64, Spring, pg. 12-40. 